\title{
Pastoral And Theological Responses To The Effects Of Witchcraft Beliefs In Ghana
}

\author{
Kwasi Atta Agyapong1 \\ ${ }^{1}$ School of Theology and Missions, Pentecost University - Ghana.
}

\begin{abstract}
The prevalence of witchcraft beliefs in Ghana is not without effect in the milieu as violence and abuses have been the bane for the people. The interpretive paradigm was the perspective that heralded this qualitative study. The study explored the views of 50 respondents from the Akan and Konkomba context. Some of the effects of witchcraft beliefs as discussed in the study are gender and age inequality, poverty, exploitation of the weak and the vulnerable, violence, abuses and others. The effects were evaluated in the light of Ghanaians progress and their linkage to how ideas or beliefs can have grim consequences on a nation. Pastoral and theological responses have been recommended for the chauvinistic paradigm. The study contributes to knowledge on curbing the effects of witchcraft beliefs in Ghana.
\end{abstract}

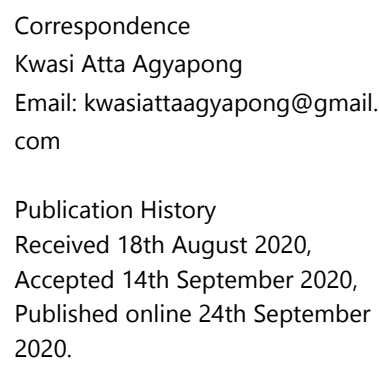

2020.

Keywords: Witchcraft Beliefs, abuse, violence, pastoral, theology

\section{INTRODUCTION}

In Ghana, as in several other African countries, belief in witchcraft is ubiquitous and deep-rooted in the indigenes. Kofi Abrefa Busia asserts that, the Supreme Being of the African is the maker and the origin of life, but amid the Supreme Being and human beings situate many powers which are either good or bad, and these account for the strange happenings in this world and one of the many powers is the witches in the Ghanaian context. ${ }^{2}$

Witches are believed to possess intrinsic, mystical powers that are used to do evil or cause misfortune. Sicknesses, sterility, accidents, the loss or destruction of property, droughts, plague, floods and fires are among the evil believed to be instigated by witches. Ghana is entrenched with the belief in the activities of witchcraft and its accompaniment violence and rituals in the milieu. Witchcraft has become one of the most common themes in Ghana's deliberations and challenges. Most popular movies in Ghana like Kyeiwaa, Efie Bayie feature prominently the witchcraft beliefs of the people of Ghana. The belief in bayie (witchcraft) is reflected in various aspects of the society, including their music, movies, and day to day activities. ${ }^{3}$ In the 21 century where science, technology and education abound, the belief in the phenomenon has stood the test of the time and their effects on the people of Ghana are glaring. Ideas or beliefs have consequences and the key to transformation lies in renewal of the mindset or worldview of the people. ${ }^{4}$ The outcome of one's life is directly proportional to the beliefs subscribed to, which often knits with the culture, socio-religious orientations and worldview.

Violence emanating from witchcraft beliefs permeates Ghanaian life and that cannot be without effects on the nation ${ }^{5}$. An Evangelical church pastor was among five people who were arrested for dousing a 72-year-old, Ama Hemmah in kerosene and setting her ablaze at Tema in 2010 which attracted so much condemnation from the country's human rights and other governmental organizations. ${ }^{6}$ Joy online in Ghana also reported of a mob lynching and the murder of

\footnotetext{
2 Kofi Abrefa Busia, The African World View: A Comparative Approach in Cultural Adaptations within Modern Africa (New York: Columbia University Teachers College Press, 1972).

3 Christian Tsekpoe, Response to witchcraft and demonology in Ghana in African Pentecostal Missions Maturing, ed. Lord Elorm Donkor \& Clifton R. Clarke (Oregon: Pickwick Publications, 2018), 143.

4 Scott Allen, Darrow L. Miller, Against All Hope: Hope For Africa (Nairobi: Samaritan Strategy Africa Working Group, 2005).

5 Jon P Kirby, “Toward a Christian Response to Witchcraft in Northern Ghana," 20 International Bulletin of Missionary Research 39 , no. 1 (2015) 19.

6 David Smith, "Ghanaian woman burned to death for being a witch" https://www.theguardian.com/world/2010/nov/29/ghanaian-woman-burned-death-witch accessed July 31, 2020 at 2:02pm.
} 
a 90 year old woman called Akua Denteh at Kafaba in the Gonja East of the Savannah region of Ghana on account of witchcraft accusation on July 24, 2020 leading to the arrest of the chief of the community and other accomplices by the Ghana Police service.

The northern part of Ghana, where all the witch camps in Ghana are situated, have realized abuses and maltreatment of people who are accused of witchcraft possession. In the colonial and post-colonial periods, witchcraft related violence has been increasing and the occurrences of witch hunt heighten. ${ }^{8}$ These beliefs unequivocally has a bearing on the Ghanaian society, as it has the propensity of nurturing people who are irresponsible as none can be blamed squarely for inefficiency or flaws because there are external agents who control their predicament. Poverty, sicknesses, barrenness, unemployment, poor governance, corrupt political life, accidents, deaths and many others are often believed to be caused by witches. This renders the Ghanaian helpless as if they are victims of witches, by way of imposing their (witches) will on them and hurting at will. Witchcraft in Ghana is more than an ethnic thread; it is the warp reinforcing the spiritual fabric of the Ghanaian society. ${ }^{9}$ The Akan people of Ghana know bayie, which Westerners have translated as witchcraft, has the audacity to inflict evil or pain on others by use of spiritual controls. Witches are believed to fly in the night and participate in spiritual human flesh-eating and blood drinking. ${ }^{10}$ Witches make people poor by spiritually eating their wealth and generating trepidation amongst Ghanaians. ${ }^{11}$

Ghana is not in this battle alone as many countries in African and beyond are suffering the consequences of the beliefs in this phenomenon. "According to BBC News India, police in Assam report that over the last five years nearly ninety people, mostly women, have been "beheaded, burnt alive or stabbed to death as a result of witch accusations." 12 Countless number of Kinshasa's orphans have been accused of witchcraft for causing the death of their own parents and often neglected to parade the streets. ${ }^{13}$ The effects of the beliefs have adversely impacted the social, emotional, psychological and economic ambiance of the people. ${ }^{14}$

An introspective flashback on the street children in Kinshasa to the killing of male witches in Peru or of elderly female widows in Tanzania, to the witch villages of Ghana or the witch burnings of New Guinea, is likely to come up as a subject in Ghana; and this creates more opportunity for missionaries, pastors, theologians and the government to engage witchcraft beliefs. ${ }^{15}$

The study proposes pastoral and theological responses to mitigate the effects of witchcraft beliefs in Ghana.

\section{METHODOLOGY}

This qualitative study seeks to describe the life-worlds of the participants from their perspectives and in their own sociocultural context. ${ }^{16}$ The interpretive paradigm was the perspective that heralded this qualitative study. ${ }^{17}$ Fifty respondents participated in the study through the purposive sampling strategy. Other related works were used as secondary sources in the study to triangulate the findings. ${ }^{18}$

\section{FINDINGS AND DISCUSSION}

\section{EFFECTS OF THE BELIEFS IN THE ACTIVITIES OF WITCHCRAFT}

Witchcraft as a malicious spirit, when inherent in human beings, makes them spiritually cannibalistic. Witches are believed to cause censures, preventing members of their own people from giving birth to children. ${ }^{19}$ In addition, the witches hinder man's prosperity and can alter man's destiny. ${ }^{20}$ Whatever prevents one from becoming become prosperous or fruitful may be attributed to witches because, "In Ghana, the concept of connecting religion and wealth is pervasive." ${ }^{21}$

\footnotetext{
Kenneth Awotwe Darko, "Police Arrests 5 more in the lynching of a 90-year- old woman at Kafaba" www.myjoyonline.com.national, accessed August 7,2020.

Shelagh Roxburgh, "Witchcraft and Violence in Ghana," Open Edition Jornal 224 (2016): 891-914, https://doi.org/10.4000/etudesafricaines.18387.

Owusu Brempong, “They Have Used A Broom To Sweep My Womb: The Concept Of Witchcraft In Ghana," Research Review (NS) 12, no. 1\&2 (1996): 42-50.

10 Kwasi Atta Agyapong, "Beliefs in the Activities of Witchcraft in Ghana," E-Journal of Religious and Theological Studies -5th Anniversary Special Edition 6, no. 6 (2020): 281-89, https://doi.org/10.38159/erats.2020092.

11 Joseph Kwabena Asamoah-Gyadu, "Witchcraft Accusations and Christianity in Africa," International Bulletin of missionary Research 39, no. 1 (2015):23-27.

12 Robert J Priest et al., "Witchcraft and Mission Studies," International Bulletin of Missionary Research 39, no. 1 (2015)1-2.

13 Robert J. Priest., "Putting Witch Accusations on the Missiological Agenda: A Case from Northern Peru," International Bulletin of Missionary Research 39, no. 1 (2015):3-6.

14 Godfred Adjei Nyarko, “The Concept of Evil in African Communities : The Case of the Yoruba , Akan and Igbo People," Journal Of Mother-Tongue Biblical Hermeneutics And Theology (MOTBIT) 2, no. 1 (2020): 21-27, https://doi.org/10.32051/motbit.2020.043

15 Robert J. Priest., "Putting Witch Accusations on the Missiological Agenda,3.

16 Kusi, Doing Qualitative Research: A Guide for Researchers,2.

17 Michael Bessey, Case Study Research in Educational Settings (Buckingham: Open University Press, 1999),43. Quoted in Hinneh Kusi, Doing Qualitative Research: A Guide for Researchers (Accra: Emmpong Press, 2012),16.

18 Uwe Flick, Triangulation In Qualitative Research, ed. I. Steinke E.V. Kardoff (London: Sage Publications, 2008 ), 178.

19 Brempong, "They Have Used a Broom to Sweep My Womb," 43.

20 Agyapong, "Beliefs in the Activities of Witchcraft in Ghana,"285.

21 Justice Anquandah Arthur, “The Gospel of Prosperity and Its Concept of Development: A Ghanaian Pentecostal-Charismatic Experience," Routledge 50, no. 3 (2020), https://doi.org/10.1080/0048721X.2020.1792050
} 
The source of evil in Ghana is attributed to the evil or sinful activities of a person (witch). ${ }^{22}$ Witches are mostly females but there are also male witches (wizards). ${ }^{23}$

The adverse effects on the beliefs in the activities of witches in Ghana have been outlined and explained below:

\section{Gender and age inequality}

It was realized from the interviews conducted that women are often tagged as possessing witchcraft compared to their male counterparts in Ghana. The supposed assertion can be buttressed by the number of witch camps in Ghana and their acceptance of men in the camp. Out of the six existent witch camps in Ghana as of 2019, it was only Gnani witch camp which accepted wizards (male witches) rendered as bcma bonsam in Akan. Any nation that discriminates based on gender and age thrives little because most of the nation's potentials and human resource are relegated to the background. An interview at Gnani witch camp in the Yendi Municipality gives a clue that, the witches rendered in the Konkomba as kisoak in the camp are mostly female and children. As of November 2018, there were about 1028 people comprising of 313 women, 105 men and 610 children. ${ }^{24}$ The NCCE reports in its study that, old persons who are mostly women are the alleged witches hostage in the witch camps of Ghana. ${ }^{25}$

The author during this study asked the interviewees the question in Figure 1 and below are the responses:

Fig. 1. Demographics of respondents

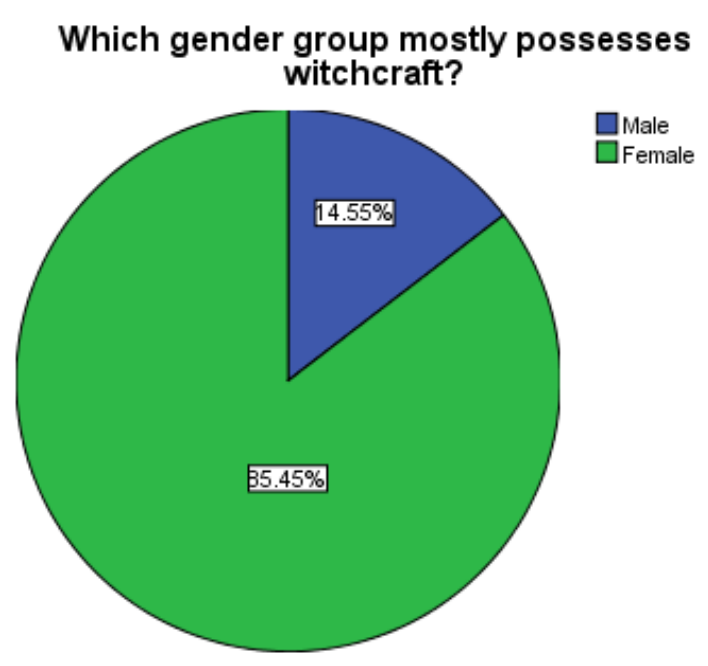

The views of $85 \%$ of the interviewees agree that female possesses witchcraft more than male. The following are some of the reasons given by some participants in the author's interview as to why female are mostly witches than male:

- Women do not show mercy compared to men (27 years old girl)

- Women are cruel compared to men (39 years married woman)

- Women have been witches from antiquity and the trend has not changed (52 years old man)

The case of Gnani witch camp further suggests that, the numbers of children who are accused of witchcraft are above the adults, making witchcraft a phenomenon believed to be practised generally by children rather than adults. The ordeals meted out on some of these children are unpleasant. The nation Ghana is hugely affected negatively, as women and children are discriminated against as far as witchcraft accusation is concerned. The universal declaration rights of 1948 sets out a list of specific human rights that all countries of the world should respect and protect. These rights can be grouped under the following: Security rights, Due process rights, Liberty rights, Political rights, Equality rights and Social or Welfare rights. ${ }^{26}$

Surprisingly witchcraft accusations in Ghana defy all these stipulated rights apart from political rights. Can a nation continue to tolerate a paradigm that defies the legislative framework that governs the land? Any nation that allows the rule of law to be violated in the name of individual or societal belief is treading on dangerous grounds.

Article (21) (c) of the Constitution of Ghana guarantees the right to religious belief, but the practice of the belief is

\footnotetext{
22 Emmanuel Foster Asamoah, “The Bible and Akan Traditional Religious Values : A Search For Dialogue” 2, no. 2 (2020): 78-86.

23 Brempong, "They Have Used a Broom to Sweep My Womb," 43.

24 An interview conducted by the author with Shei Alhassan (Chief Priest of Gnani Witch camp) on November 2, 2018 at Gnani witch camp.

25 Research Department of the National and Commission For Civic Education (NCCE), "Witchcraft and Human Rights of Women in Ghana : Case Study of Witches Villages in Northern Ghana," NCCE Research Reports II, no. 2007-2011 (2010),23.

26 Mary Ohenewaa Afful, The Fundamental Human Rights and Freedoms (Accra: LIEC, 2011$), 4$.
} 
subject to controls in the interest of public health, morality and safety. Sydney J. Harris posits that, people want to be appreciated, not impressed. They want to be regarded as human beings, not as sounding boards for other people egos. They want to be treated as an end in themselves and not as a means towards the gratification of another's vanity. ${ }^{27}$

A critical study of the phenomenon suggests that, the beliefs in the activities of witches in Ghana seem to impose one's belief on another which defies the above assertion because someone is stigmatized because another person believes some spirit of evil intent dwells in another person. A study of the development of human rights laws in Ghana postulates that, the independence constitution in 1957, the 1960 constitution, the 1969 constitution, the 1979 constitution and the 1992 constitution highlights the dignity of the rights of Ghanaians which cannot be trampled upon. Despite the above constitutional mandate that protects the dignity of Ghanaians; most people are accused of witchcraft and molested. Alleged witches are often detained in witch camps which defy the constitutional decree of security rights, due process rights, liberty rights and equality rights. Other accused witches are camped at traditional shrines in some Akan lands. Kofi Badu a former traditional priest at Nkawkaw in the interview asserts that, when someone is accused of witchcraft or se bosom bo obi a, the alleged witch must confess all sins and afterwards a fowl shall be killed to appeal to the gods to unravel the wholeness of the truth in the confessions made by the accused witch. Afterwards the entire hair of the accused witch will be shaved off, to minimize the witchcraft powers. ${ }^{28}$

The Author is of the view that any nation that accepts the humiliation of her citizenry to such an extent will end up having indigenes whose ego or self-confidence are marred. It is imperative that the nations legislature will work as far as curbing the trend where generally, female and children are discriminated against, accused as witches and chastised for perhaps a phenomenon they might not know so much about.

Jayon a victim of witch accusation at the Gnani witch camp asserts in the interview granted during the study that, "I don't know what witchcraft is, but a young girl who had gone to fetch water was bitten by a snake and she died, thereafter, I was accused as the witch behind the incident and was brought to the witch camp." 29 This is how beliefs in the phenomenon have rendered some members of the Ghanaian communities into jeopardy, humiliation and psychological traumas.

\section{Children drop outs from school}

The huge masses of children accused of witchcraft are confined to either witch camps, prayer camps, traditional shrines or others for exorcism. A nation that run on beliefs that has the tendency to thwart the education of her children might live in regret and shame in the years ahead. The nation Ghana has held on to these beliefs about the phenomenon for a very long time and the state of the nation's socio-economic development seems to be at par with some of the beliefs subscribed to. Ghana cannot grow beyond her thinking and if the thinking or beliefs system is faulty, it inadvertently affects the entire development of the nation. Article 25 of the 1992 Constitution declares that all persons have the right to equal educational opportunities and facilities and with a view to achieving the full realization of that right. Basic education shall be free, compulsory and available to all.

Despite every child's right in Ghana to access education freely, compulsory and its availability to all, some children are accused of witchcraft and confined to camps which often prevent them from schooling as their rights in the Ghanaian constitution mandates. The judiciary must enforce the rule of law in this regard as lots of talents in Ghana are made waste or unharnessed due to the neglect of this constitutional mandate. Any nation that needs development cannot undermine education as it serves as the foundation, without which the future is scary. The future of Ghana becomes gloomy if the children cannot access quality education which should have been accessible by all, but reduced to living at witch camps, prayer camps and traditional shrines because of beliefs in witchcraft.

\section{Poverty}

The setbacks and poverty in Ghana is due to the fact that some people attribute their ineffectiveness to witches, hence will do nothing about them because they are not responsible. Below are two agricultural analogies to present the relationship between ideas and real life: The seed (ideas, beliefs) that an individual sows will determine his/her fruit (real world consequences like poverty, prosperity) to reap. ${ }^{30}$ To an extent Poverty is neither accidental nor invoked upon by an external agent but a choice that can only be made, that notwithstanding, most respondents in this study argue that poverty is caused by witches. People often go to church to pray against the witches that makes them poor. Just as the

\footnotetext{
27 Ibid.

28 Personal interview conducted by the Author with Nana Kofi Badu on October 20, 2018 at Nkawkaw (practicing fetish priest for 43 years).

29 Personal interview conducted by the Author with Jayon Mpagna (accused witch). on November 3, 2018 at Gnani Witches camp.

30 Allen and Miller, Against All Hope: Hope For Africa ,31.
} 
quality of the soil and roots of a tree determine the quality of the fruit produced, so is it with ideas and beliefs. ${ }^{31}$ Could the fruit of underdevelopment or poverty in the physical realm be remote caused by a metaphysical phenomenon rather than the physical root?

Ghanaians beliefs and development are intertwined and dependent on each other. The right belief produces the right and expected output. The right antidote to a disease can only be prescribed when the right diagnosis is made. Ghana's poverty can only be dealt with when the mindset on what is causing poverty is refined.

\section{People refuse medical treatment because they think their diseases are witch induced and cannot be scientifically or medically handled.}

The data gathered from interviews in this study and other related literatures postulates that witches can cause sicknesses in human beings. The challenge to battle with becomes what particular diseases are witch induced and which ones are not. Most people prefer seeking spiritual solutions when they are sick than to seek medical attention from qualified medical practitioners. A twin nurse the author interviewed said, "I lost my twin sister because, I was ignorant: my sister had been kept at the prayer center for about one month and when the situation grew worse, we visited the hospital and the physician said, our delay will ultimately result in her death and I lost my sister to typhoid fever." ${ }^{32}$

If Ghana can work on this, some people who would have died will be alive to contribute their quota to the development of the nation. The chief priest of Gnani witch camp posits that "witches causes misfortune, sickness and death." ${ }^{33}$ In Ghana, it is generally believed that, every physical condition has gotten a spiritual linkage and that the spiritual dominates the physical. ${ }^{34}$

\section{Severs relationships amongst families and close relatives}

Witchcraft accusations tear families apart as Ghanaians mostly flee from an evil witch relative or friend. At the Gnani witch camp it was realized that most of the accused witches at the camp are widows, because they are often accused of eating their husbands and as a result, severed from their families. Powuni a Gnani witch camp dweller in the interview asserts that "the death of my husband brought me here,"35 when she was asked what brought her to the witch camp. Another woman's reason for being at the Gnani witch camp was due to the fact that a family member dreamt and saw her chasing him. The beliefs and the activities of witchcraft in Ghana tend to create enemies amongst relatives as one is accused of witchcraft when perceived evil strikes. The stigmatization of witchcraft automatically creates family disputes.

At the prayer camp of Prophet Ebenezer Adarkwa Yiadom of Ebenezer Miracle Centre in Kumasi, suspected witches are often sent to him for approval or disapproval of the accusation and broadcast at Prophet $1 \mathrm{TV}$, which is similar to what transpires at the Gnani witch camp in affirming/refuting witchcraft accusation. Same practice is carried out at the prayer camp of Rev. Obofour and is telecast almost daily at the Sweet TV on the multi TV channels. Rev. Obofour said on Sweet TV on Sunday 25 ${ }^{\text {th }}$ November, 2018 at 7:53 a.m., 'if somebody buys from your shop and you notice that business is not booming, don't sell to him again'. A common belief in Ghana is that, when things are not thriving as expected, there is a possibility that, a witch might be plying that route. Why are all retrogressions tied to witchcraft? Is it possible that inefficiency, laziness and wrong beliefs can also smother growth or breed evil?

Rev. Obofour made an altar call for witches at his church and about 15 people responded and said they were witches and were telecast on Sweet TV on November 25, 2018 at 8:17 a.m.; about 60\% were children, while female constituted about $94 \%$. Amongst the fifteen people who said they were witches, only one was a male. The male said he was not sure if he had witchcraft but was accused by the family and wanted to come for verification. One child said, it was her mother who said she was a witch and Rev. Obofour said, because she has not accepted custody of witchcraft, the witchcraft spirit would return to the child again when he exorcised it. Rev. Obofour continued by saying that, the head of the child is a dog in the spirit realm and she will go mad later and the parents should bring the child to him when that happens. Thus, the child may suffer this stigma all her life and the family might somehow neglect her because of the assumption that, she possesses a malevolent spirit (witchcraft). One of the children said she did use her witchcraft to kill some people in her family and has destroyed the work of her parents. Witchcraft accusations tend to create tension amongst family relations and as result tear them apart. Witchcraft is not less foreseen than any other thing in everyday

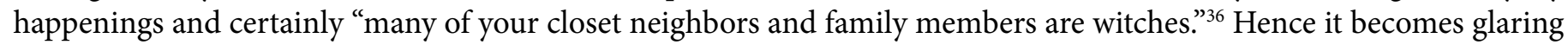
how Ghanaians are afraid of themselves, for the dread of being bewitched.

\footnotetext{
Ibid.

32 Personal interview conducted by author with Ataah Adwoa (nurse) on October 26, 2018 at Nkawkaw.

33 Personal interview conducted by author with Shei Alhassan (Chief Priest of Gnani Witch camp) on November 2, 2018 at Gnani Witch camp

34 J.P. Timmons, Mysterious Secrets of the Dark Kingdom: The Battle for Planet Earth (U.S.A.: Zondervan Bible Publishers, 1984),24.

35 Personal interview conducted by author with Powuni Idongnan (Accused witch) on November 2, 2018 at Gnani Witch camp

36 Evans Evans-Pritchard, Witchcraft, Oracles and Magic among the Azande (Clarendon: Oxford, 1937),19.
} 


\section{Non-law abiding people abounds}

In Ghana where witchcraft beliefs are widespread, people always want to attribute their vices and lawlessness to witches. It is normal in Ghana for people to seek clemency with this maxim, "it's not me, but witches influenced me." Since most atrocious acts are attributed to witches, people have a way of shirking responsibility by blaming witches for acts of mistakes or wrongs committed. This pattern has a way of encouraging immoralities and contrariness as vices are not generally tagged to the doers. It is glaring why some people in Ghana are non - law abiding people, because it is possible they might go unpunished. God is just means that, sin must not go unpunished. Any nation that continues to believe that lawlessness is influenced by witches will continue to encourage vices because their evil will not be attributed to them. The concept of witchcraft provides the natural philosophy by which unfortunate events are explained. ${ }^{37}$

\section{Exploitation of the weak and the vulnerable by the strong and affluent}

The phenomenon of witchcraft simply tramples on foot the weak and vulnerable in the nation. It has already been established that the stigma of witchcraft mostly affects women and children who are known to be the weaker sex per the Ghanaian context. Why will the weak mostly possess witchcraft other than the supposed stronger ones? Why will most witch camps in Ghana exist to only house females and not males? Does witchcraft equal the weak or the marginalized in the Ghanaian society? Amongst the women, who are most vulnerable to witchcraft accusations, it is unusual to come across a rich female person accused of witchcraft. Most often it is the poor ones that are accused of the phenomenon. Ghana as a nation is supposed to protect the weaker ones, but on the contrary, her beliefs in the activities of witchcraft are rather inflicting the vulnerable and the ostracized in the society. "There are also good and bad witches. Good witches are believed to be found in prosperous families; families endowed with children, wealth and prestige whiles bad witches are from poor and a suffering context." 38

There are witches also among Europeans, but they use their witchcraft not in imprisoning people or doing evil, but for making beneficial things. ${ }^{39}$ The woman whose child appears to get on in life is said to be using her witchcraft well, and it is in this sense that the European witches were said to be generally better according to Jehoda. ${ }^{40}$ Witchcraft from this standpoint seems to possess the weak and vulnerable but the strong and the affluent are exonerated.

\section{Violence and Abuses of the rights of people}

In the northern part of Ghana, hundreds of people especially women are accused of witchcraft by relatives or members of their community, hence living in witch camps after fleeing or being displaced from their homes. They have absconded from stigmatization, discrimination, threats or even mob justice after being accused of witchcraft and blamed for evils such as causing illness, famine, fire outbreak, cursing a neighbor or appearing in someone's dream. ${ }^{41}$

Those who hit the witch camps are the fortunate ones. Generally, most women have been assassinated after accusations of witchcraft. In 2010, the case of a 72-year-old woman who was set on fire and killed made headlines around the world. ${ }^{42}$ Witchcraft accusations in Ghana equals violence and abuses meted unto alleged witches, who are victims of the beliefs of the Ghanaian society. The victims are ill-treated and relegated to live at witch camps, prayer camps, and traditional shrines or simply thrown out of their abode. These experiences are issues of human rights abuses because they trespass upon the rights of these accused persons. The 1992 Constitution of Ghana plainly specify in Chapter 5, Section 15 (2a) that no person must be imperiled to cruel, inhuman or debasing punishment or treatment, yet there are victims in this regard. ${ }^{43}$

In 2011 the Ghana government announced that, all witch camps in Ghana should be closed down as soon as 2012. Action Aid stood firmly against the closure of the camps in such a short space of time, because although they can be seen as against the rights of the people hostage there, the camps do provide a safe haven for persons accused of witchcraft. ${ }^{44}$ The witch camp dwellers themselves, have asserted in the interviews conducted by the author at Gnani witch camp that, they would prefer to stay in the camps rather than the stigma, violence or death in their communities.

\section{EVALUATION OF THE EFFECTS OF THE BELIEFS IN WITCHCRAFT ACTIVITIES}

The effects of the beliefs in the activities of witches as outlined above are enormous to corroborate the magnitude of its adverse impact on the nation and the indigenes. The effects have to an extent affected the social, emotional, psychological

\footnotetext{
37 Ibid, 18.

38 Brempong, "They Have Used a Broom to Sweep My Womb," 44.

39 Gustav Jahoda, Whiteman (London: Oxford university press, 1961),29. Quoted in Brempong, "They used a broom to sweep my womb," 44.

40 Jahoda, Whiteman, 29.

41 Awaba Damba et al., "Condemned without Trial : Women and Witchcraft in Ghana" (Action Aid, 2012), 3. http://www.actionaid.org.uk/.../ghana.

42 David Smith, Ghanaian Woman Burned to death, Accessed in August 17, 2020, www.guardian.co.uk/world/2010/nov/29/ghanaian-woman-burned-death-witch 3

431992 Constitution of the Republic Of Ghana. Italics are mine for Emphasis

44 Damba et al., "Condemned without Trial : Women and Witchcraft in Ghana,"3.
} 
and economic milieu of the nation. As devastating as the belief is, it seems the people of Ghana are not putting in measures to do away with the paradigm. The continuous presence of the beliefs in witchcraft issues will still have a rippling effect on the nation and her people. The consequences of the chauvinistic paradigm, upheld by some Ghanaians will continually worsen the plights of the nation as well as cause them to animate in fantasy, whiles it is advantageous to resonate on realities. The substratum of success to any nation is their ability to tap the wisdom and insight to device practical explanations and solutions to their challenges. It seems, the conceptual framework of interpretation, for the average Ghanaian starts from who is plotting evil against one's enterprise and most often, they boil down to the witches. Why am I sick now? Why did I fail the examinations? Why is the church not growing? Why has the community road not been tarred for such a long time? The spirit is a quick-fix solution to life's distress and challenges. ${ }^{45}$

Generally, in Ghana witchcraft is a ready answer to life's difficult situation and this brings respite to the responsible officers and persons who are supposed to work. Responsibility is vital in the development of any nation and irresponsibility profits ignominy and messes. Most of Ghana's challenges are directly proportional to the paradigm and perspective they uphold. ${ }^{46}$ Ideas always have consequences as asserted by Max Weber.

There is therefore a need to develop holistic pastoral and theological responses to curb the anomaly. Below are pastoral and theological responses proposed by the author to surmount the beliefs in the phenomenon.

\section{PASTORAL RESPONSES TO WITCHCRAFT BELIEFS IN GHANA}

The following pastoral recommendations are made to address the witchcraft beliefs in Ghana. The predisposition in Ghana, where females have been stigmatized to possess witchcraft should stop as that is a step towards misogyny. Gender equality programmes should be included in the schools' curricular and taught from the Kindergarten level through to the tertiary level by the Ministry of Education.

The legislative framework in Ghana should become an advocate for the ostracized (female, children and the poor) who are most often victims of witchcraft stigmatization. All persons and gender should be given equal rights and admittance into the Ghanaian society and not discriminated against.

The government and religious organizations should device strategies to take out all the children housed in witch camps and relocate them, so they can have access to education in the interest of the Ghanaian society and the victims involved. Abandoned children who are not cared for nor schooled often turn out to become liabilities to the nation instead of assets and hence the need to dispossess the witch camps of the hostage children.

All persons who pervert the orders of the society with the intention of blaming them on witches should not be considered, but made to face the law as and when necessary. Most Ghanaians would beg to be forgiven when they violate the laws of the land, on the premise, that the committed act was as a result of witches or evil spirits that took hold of them. The Author does not suggest that an evil spirit cannot possess someone to do evil, but if all Ghanaians are to be possessed and act otherwise, what would be the story of Ghana?

The government, institutions, churches and NGOs should continue to educate the Ghanaian society on the need to seek medical attention when they are sick and stop the chaining of mentally deranged people at traditional shrines, prayer camps and by Mallams (medicine men). Jesus Christ is the healer and he is the same yesterday, today and forever (Hebrews 13:8). That notwithstanding, seeking medical attention is approved by the Bible. The Ghanaian society should be taught to wake up from its slumber, since most of the sickness that people claim to be witch induced can be explained scientifically and treated.

Communities and societies that are often known for witchcraft accusations and subsequent abuses should be checked. The government, religious institutions and all stakeholders must come on board to fight against this scourge of accusing people with the requisite education to change their perspective. Most people accused of witchcraft are victims of mental disorders (depression, hysteria, dementia, hallucinations, etc.). Additionally, those who often accuse people of witchcraft because they see them in their dreams might possibly be suffering from mental disorders and a need to refer them to counseling for psychotherapy. The government, non-governmental organizations, and religious bodies need to send more clinical psychologists and counselors to areas where people are often accused of possessing witchcraft. Christian leaders and Ghanaians in general, must accept people who subscribe to extremes in witchcraft beliefs, as having genuine problems that need to be worked on.$^{47}$ Christian Leaders should meticulously provide interpretations for the people of Ghana using the word of God to address their poverty, sickness, barrenness, evil and all forms of human affliction so that they will not be left in the dark.

Religious organizations may also explore the possibility of teaching witchcraft issues in mission schools and thereby educating them aright on the phenomenon, so as to demystify witchcraft beliefs that pertain in the Ghanaian

\footnotetext{
45 Tsekpoe, Response to witchcraft and demonology in Ghana, 157.

46 Agyapong, "Beliefs in the Activities of Witchcraft in Ghana," 288.

47 Allan H Anderson, Witchdemonology, Witchcraft and Deliverance in african pentecostal missions maturing, ed. Lord eLorm donkor \& Clifton R. Clarke (Oregon: Pickwick Publications, 2018),124.
} 
society. The Pentecost University has a programme called Witch-demonology, initiated by Opoku Onyinah and the Author recommends such programme for all mission schools in Ghana and a possible extension of this course to all public schools in Ghana.

Advocacy ministries for accused witches must be formed within religious organizations, NGOs and the government. Awareness creation of the beliefs in the phenomenon and education must be targeted to Ghanaians at all levels, including traditional leaders, women, youth groups, children, media, National Commission for Civic Education (NCCE), Commission on Human Rights and Administrative Justice (CHRAJ),Domestic Violence and Victim Support Unit (DOVSU), Imams, priests, assemblymen/women, teachers, churches and parliamentarians. ${ }^{48}$

The Ghana government must do more to support the victims at witch camps who are deprived of the basic amenities for life, pending the dissolution of the all witch camps in Ghana, through systematic and pragmatic interventions aimed at educating the communities where these witch camps are situated. The hostage victims can be provided with interim support aimed at educating them to become useful citizens of the nation. The health of these victims at the various witch camps must not be taken for granted.

\section{THEOLOGICAL RESPONSES TO WITCHCRAFT BELIEFS IN GHANA}

Christians make up one-third of the world's population, ${ }^{49}$ and $70 \%$ of Ghana's population according to the 2010 Ghana national statistical department report. A well-intentioned theology that can reshape Ghana's perspective on a phenomenon should be from the Christian perspective, because they are the majority and a major stakeholder in the country, that notwithstanding, a theological discourse from other faiths will complement the fight against this anomaly. The theological responses in the study will be from the Christian perspective in particular but generally verified by all the major religions in Ghana. Debrunner posits that, Christianity is considered as absolutely opposite to the old traditional religion and it is expected to safeguard the communities from witches. ${ }^{50}$

The author in this study proposes a comprehensive theology that can adequately help Ghanaians to overcome their fears and thereby change their mindset in the beliefs in the activities of witchcraft. Below is what has been proposed to get Ghanaians unstuck from the beliefs that stifle growth and generate violence in the milieu. In developing a theological response to a cultural challenge, the phenomenon and the context being studied is subjective to the Scripture which is objective, whiles not thrashing wholly all the elements in the cultural context.

Syncretism might occur "when critical and basic elements of the Gospel are lost in the process of contextualization and are replaced by religious elements from the receiving culture." ${ }^{51}$ The author took into consideration, the peril of syncretism in developing a Christian theology for a cultural challenge in same context. "Witchcraft is the strongest survival of the old paganism in Ghana and therefore very crucial as far developing a theology to restrain it is concerned." 52 The theological responses seek to use scripture to throw light on the Ghanaian beliefs on witchcraft.

\section{The Human Being, created in the Imago Dei (Image of God)}

The human being is created in the image of God making the human person a unique creation among the millions of God's creation on the earth. ${ }^{53}$ God choose himself as the model in the creation of humanity. ${ }^{54}$ Human Beings are not products of evolution as some secularists propound. God being the overall maker of all that exists, choose to give human beings his earth to occupy and work on it. ${ }^{55}$ "This fact that humans are God's image bearers is referred to as the doctrine of Imago Dei. The doctrine of the Imago Dei informs the nature of humanity as individuals and as a corporate entity and serves as key basis for the Christian valuation of human life." ${ }^{6}$

God's instruction to the man He created in the Garden of Eden was to work the land and thereby bring transformation and growth to the quality and the state of the resources entrusted to their care. God is always concerned about the development and growth of whatever He has entrusted to mankind. The reason he applauded the servants who worked and multiplied the talents that were entrusted to them in the parable of the talents was their ingenuity, creativity and innovation which actually portrays the Imago Dei in man as in Genesis 1:27-28 and Luke 19:13-20.

God never compromises when it comes to development and growth of individuals, communities and nations.

\footnotetext{
48 National Commission for Civic Education (NCCE), "Witchcraft and Human Rights of Women in Ghana : Case Study of Witches Villages in Northern Ghana,"147.

49 Priest et al., "Witchcraft and Mission Studies, 28-29."

50 Hans. W. Debrunner, A History Of Christianity in Ghana (London: Spottiswood, Ballantyne and Co. Ltd., 1967$), 311$.

51 Peter S.J. Schineller, “Inculturation and Syncretism: What Is the Real Issue?," International Bullettin of Missionary Research, 1992, 50-53 . Quoted in Harvie M. Conn, Eternal Word and Changing Worlds (Grand Rapids, Mich.: Zondervan Publishing House, 1984), p. 176.

52 Debrunner, A History Of Christianity in Ghana,311.

53 Genesis 1:26, (And God created man in his own image, in the image of God created he him; male and female created he them, ASV).

54 Allen and Miller, Against All Hope: Hope For Africa, 15.

55 Luke 19:13, (And he called ten servants of his, and gave them ten pounds, and said unto them, Trade ye herewith till I come, ASV).

56 Isaac Boaheng, “The Doctrine of Imago Dei and the Challenge of Euthanasia," E-Journal of Religious and Theological Studies (ERATS) 6, no. 3 (2020): 158-68, https://doi.org/10.38159/erats.2020062
} 
The Imago Dei in human being requires that God's creation on earth becomes progressive as far as sustaining and improving the quality of whatever He has entrusted to humankind's care is concerned. The study brought to light that, the Ghanaian beliefs in the activities of witchcraft has affected the development of individuals and the nation as a whole and Ghanaians must tap the potentials and resources embedded in human beings as the Imago Dei on earth. The world today applauds those who are continually developing their God endowed talents and that explains what the Bible asserts in the parable of the talent in Luke 19:24. The servant, who had much, was given the talent of the one who had few and could not develop the talent received. Ghana's mineral resources far supersede the wealth of most western and advanced nations of the world; that notwithstanding, Ghana is still a developing nation. It is a glaring fact that most foreign companies and wealthy nations are taking advantage of Ghana and exploiting the nation because, the human and mineral resources given to Nation by God is kept underneath and unharnessed, just like the lazy and unfaithful servant in Luke 19:13-20.

Ghana is not among the Third World Countries by accident or by the design of God, but because of the ideas or worldview subscribed to and their priorities for life. Ghana being a nation, where her people who are supposed to till the ground to increase their capacity are accused of witchcraft and banished from their homes or place of work to live in witch camps cannot boast of development nor growth. If the Imago Dei in the human being is properly utilized, it would bring to halt gender inequality and children stigmatization and Ghana may see growth and development at both individual and corporate level.

God's image in the human being is an immense dignity and a huge investment that must taken advantage of, otherwise this may deny the nation of her capacity to prosper. Witchcraft beliefs tend to overlook the Imago Dei in human beings, thereby accusing them and subjecting them to stigmatization, mass lynching, and confinement at prayer camps, traditional shrines or witch camps. When the dignity of the human person is stressed upon and taught in the Ghanaian communities, it will create further enlightenment among those who exploit other human beings in the name of witch hunting which would in turn stop that demeaning attitude.

The Imago Dei in the human person is an immense capital and this great wealth is inherent in each individual. The human being has a mind to reason and to think Godly thoughts without cruelty or violence. Additionally, God gave the human being a heart to dream, imagine and have emotions that feel for his or her fellow human beings and treat them with dignity. The Imago Dei in the human being gives all humanity a personality that is kind.

The witchcraft beliefs in Ghana and the way it handles human beings defy the essence of being human and the image of God in the human person. Ghana's development hinges on the need to treat fellow human beings with dignity and pride as persons with the Imago Dei resident in all persons regardless of gender and age.

\section{Enthronization of the Holy Spirit}

The term enthronization of the Holy Spirit in this study means that, the Holy Spirit will be given pre-eminence or duly acknowledged in all issues and decisions of lives. The enthronement of the Holy Spirit in an individual's life must be stressed. Those that are led by the Spirit of God are the sons of God (Rom 8:14). In recent Ghanaian life, it should be noted that the greatest challenge is not the existence of witches, but the sideline of the Holy Spirit who gives strength to the believer to overcome all evil powers. There seems to be so much artificiality in the Christian life, leading to the humanization of the gospel and materialization of life by most Christians in Ghana. The center of gravity is continually shifting from Christ to the periphery. Man must not be at the center of the gospel but Christ, hence the term humanization of the gospel. The test tube is gradually taking over from the Spirit of God. Laws and praxis of Christian institutions are gradually replacing the Spirit filled life (Gal 4:4-6). All that matters in life should not be premised on material things only (materialization of life) but eternity should be the focus.

Christians must be taught to have an intimate relationship with the Holy Spirit (1 Cor 14:13). The Holy Spirit is the teacher and the guide of the Christian (John 16:13-15). Individual believers should allow the Holy Spirit to reign in their lives and witchcraft will not be an issue to contend with in Ghana. The Holy Spirit's role in a believer, especially, the purpose of the baptism of the Holy Spirit, which is so crucial to Pentecostal ministry, should be stressed. ${ }^{57}$ The Holy Spirit is the person who can transform the victims of witchcraft beliefs in Ghana to victors who can help build a glorious nation. The economy, governance and the spiritual life of Ghana will see light, when the Holy Spirit is given pre-eminence in all issues as well as belief systems.

\section{The believers' authority should be stressed}

The issue of witchcraft has gained so much grounds and prominence in Ghana because most Christians are not aware of who they are in Christ. All persons who believe and receive Christ are given power to become children of God (John 1:12). The number of Christians in Ghana who fear witchcraft is alarming and they most often express their fears

\footnotetext{
Opoku Onyinah, Pentcostal Exorcism: Witchcraft and Demonlogy in Ghana (Blandford Forum: Deo Publishing, 2012),278.
} 
through their prayer. One may actually observe tension in church when witches are being prayed against as if that topic is the most important item amongst the prayer themes mentioned at church services. The power at the believer's disposal, which makes him or her a child of God, must be the focus and not witchcraft power. What emerges clearly from the ministry of those who subscribe to the excesses in the witchcraft beliefs is the ignorance of their identity in Christ. ${ }^{58}$ If children, then heirs; heirs of God, and joint-heirs with Christ; if so be that we suffer with him, that we may be also glorified with him (Rom 8:17 ASV). Being a Christian means that, Christ has taken the center stage of one's life and therefore believers are the full possession of Christ. Since they are fully possessed, there is no emptiness for the witches to captivate. This should not be understood as, no evil or misfortune will not befall a Christian.

"Then said Jesus unto his disciples, "If any man will come after me, let him deny himself, and take up his cross, and follow me" (Matt 16:24, ASV). And when he had called the people unto him with his disciples also, he said unto them, "Whosoever will come after me, let him deny himself, and take up his cross, and follow me" (Mark 8:34). Christianity should not be understood as problem free religion, but Christ the master has assured believers that, he will deliver them out of troubles (Heb 13:5) and will strengthen them to endure hardship and not necessarily delivering them out of the trouble always (2 Cor 12:7).

The believers' authority is premised on the fact that Jesus overcame the devil on the cross at Calvary and that victory was won for all believers (Col 2:14). "You are of God, my little children, and have overcome them: because greater is he that is in you than he that is in the world" (1 John 4:4). Believers must not struggle with witches for victory, the battle between mankind and the evil powers of this world is not for man to fight, man only needs to appropriate the victory won by Christ to his advantage. The right to Christ's victory is the "Son ship" of God (Rom 8:17). If believers will understand the work of Calvary and accept it, with all its rights and privileges, witchoraft beliefs and activities will not be a challenge in Ghana.

\section{RECOMMENDATIONS}

- The study recommends that witchcraft should not be seen as a phenomenon practised by women and children as that equals undeserved discrimination and abuse of human right laws of Ghana.

- All children hostage at the witch camps in Ghana should be freed and provided with education as their rights demand through an executive instrument or a jurisdictive edict. Laws must be enacted to penalize those who perpetrate abuses on accused witches in Ghana. The government, religious organizations, NGOs and institutions must dialogue on witchcraft issues and thereby demystify the beliefs that asphyxiate development.

- The educational curricula should be structured to assuage animistic beliefs whiles not drifting to secularism. Practical and methodical processes must be devised to exhume the best in life instead of blaming witches (spirits) for retrogressions in individuals and national life.

The recommendations made in respect of pastoral and theological responses to the effects of the phenomenon being studied are key to the development of Ghana and citizenry.

\section{CONCLUSIONS}

The negative effects of witchcraft beliefs and activities in Ghana include but not limited to gender and age inequality, children drop out from schools, poverty, refusing medical treatment because of the thinking that diseases are witch induced, severing of relationships amongst families and close relatives, violence and abuses, non-law abiding people increases and exploitation of the weak (women and children) in Ghanaian societies. Ghana's challenge in this regard will be mitigated when beliefs in the activities of witchcraft are responded to adequately.

Pastoral and theological responses are recommended to adequately curtail the effects of witchcraft beliefs in the milieu as well as equip the citizenry with the armory that will effectively help Ghanaians to come out of the fear of the life threatening forces and thereby promote growth and development in the nation if adhered to. Moreover, the Christian fraternity who are the majority in the nation, other religious bodies, non-governmental agencies, government institutions, the judiciary and the legislature should all be involved in the pursuit to eradicate the bigoted paradigm. The belief or worldview of a people has a story to tell and it is connected or tied to their development. The wrong belief hinders the development of the people whilst the right belief or worldview triggers growth, development and the prosperity of individuals and nations.

\section{ABOUT AUTHOR}

8 Ibid, 278. 
Agyapong Kwasi Atta holds a Master of Arts in Pentecostal Studies from the School of Theology and Missions, Pentecost University. District Pastor, The Church of Pentecost, Nkawkaw Asuboni, Nkawkaw, Eastern Region- Ghana.

\section{BIBLIOGRAPHY}

Afful, Mary Ohenewaa. The Fundamental Human Rights and Freedoms. Accra: LIEC, 2011.

Agyapong, Kwasi Atta. "Beliefs in the Activities of Witchcraft in Ghana." E-Journal of Religious and Theological Studies -5th Anniversary Special Edition 6, no. 6 (2020): 281-89. https://doi.org/10.38159/erats.2020092

Anderson, Allan H. Witchdemonology, Witchcraft and Deliverance in African Pentecostalism. Edited by Lord \& Clifton R. Clarke Elorm-donkor. Oregon: Pickwick Publications, 2018.

Asamoah, Emmanuel Foster. "The Bible and Akan Traditional Religious Values : A Search For Dialogue" Journal of Mother-Tongue Biblical Hermeneutics and Theology 2, no. 2 (2020): 78-86.

https://doi.org/10.38159/motbit.2020081

Asamoah-Gyadu, J. Kwabena "Witchcraft Accusations and Christianity in Africa," International Bulletin of missionary Research 39, no. 1 (2015):23-27.

Arthur, Justice Anquandah. "The Gospel of Prosperity and Its Concept of Development: A Ghanaian PentecostalCharismatic Experience." Routledge 50, no. 3 (2020). https://doi.org/10.1080/0048721X.2020.1792050

Bessey, M., Case Study Research in Educational Settings. Buckingham: Open University Press, 1999.

Boaheng, Isaac. "The Doctrine of Imago Dei and the Challenge of Euthanasia." E-Journal of Religious and Theological Studies (ERATS) 6, no. 3 (2020): 158-68. https://doi.org/10.38159/erats.2020062

Brempong, Owusu. "They Have Used a Broom to Sweep My Womb: The Concept of Witchcraft in Ghana." Research Review (NS) 12, no. 1\&2 (1996): 42-50.

Busia, Kofi Abrefa. The African World View: A Comparative Approach in Cultural Adaptations within Modern Africa. New York: Columbia University Teachers College Press, 1972.

Damba, Awaba, Mariama Adam, Mariama Iddrisu, and Sanatu Kojo. "Condemned without Trial : Women and Witchcraft in Ghana." 2012.

Debrunner, Hans. W. A History Of Christianity in Ghana. London: Spottiswood, Ballantyne and Co. Ltd., 1967.

Evans-Pritchard, E. Witchcraft, Oracles and Magic among the Azande. Clarendon: Oxford, 1937.

Flick, U. Triangulation In Qualitative Research. Edited by I. Steinke E.V. Kardoff. London: Sage Publications, 2008.

Jahoda, Gustav. Whiteman. London: Oxford university press, 1961.

Kirby, Jon P. "Toward a Christian Response to Witchcraft in Northern Ghana." 20 International Bulletin of Missionary Research 39, no. 1 (2015):19-22. https://doi.org/10.1177/239693931503900106

Kusi, Hinneh. Doing Qualitative Research: A Guide for Researchers. Accra: Emmpong Press, 2012.

Miller, Darrow L. and Scott Allen. Against All Hope: Hope For Africa. Nairobi: Samaritan Strategy Africa Working Group, 2005.

Nyarko, Godfred Adjei. “The Concept of Evil in African Communities :The Case of the Yoruba, Akan and Igbo People." Journal Of Mother-Tongue Biblical Hermeneutics And Theology (MOTBIT) 2, no. 1 (2020): 21-27. https://doi.org/10.32051/motbit.2020.043

National, Research Department of the, and Commission For Civic Education (NCCE). "Witchcraft and Human Rights of Women in Ghana : Case Study of Witches Villages in Northern Ghana." NCCE Research Reports II, no. 2007-2011 (2010).

Onyinah, Opoku. Pentcostal Exorcism: Witchcraft and Demonlogy in Ghana. Blandford Forum: Deo Publishing, 2012.

Peter Schineller, S.J. “Inculturation and Syncretism: What Is the Real Issue?" International Bulletin Of Missionary Research 16, no.2 (1992): 50-53. https://doi.org/10.1177/239693939201600201

Priest, Robert J, Philip Gibbs, Steven D H Rasmussen, Hannah Rasmussen, Jon P Kirby, John P Martin, Kevin Xiyi Yao, and Michael Nazir-ali. "Witchcraft and Mission Studies." International Bulletin of Missionary Research 39, no. 1 (2015).

Roxburgh, Shelagh. "Witchcraft and Violence in Ghana." Open Edition Jornal 224 (2016): 891-914.

https://doi.org/10.4000/etudesafricaines. 18387

Timmons, J.P. Mysterious Secrets of the Dark Kingdom: The Battle for Planet Earth. U.S.A.: Zondervan Bible Publishers, 1984.

Tsekpoe, Christian. Witchdemonology, Witchcraft and Deliverance in african pentecostals missions maturing. Edited by Lord Elorm Donkor \& Clifton R. Clarke. Oregon: Pickwick Publications, 2018. 